Agroprimatech

Vol. 3 No. 2, April 2020

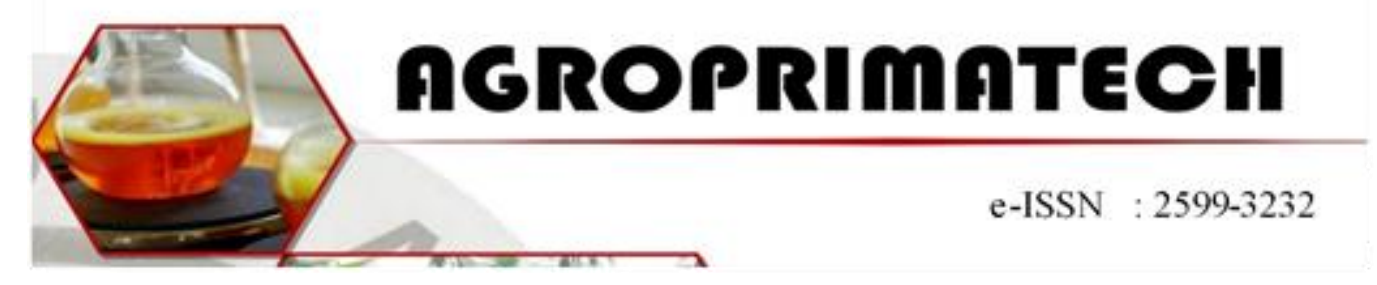

\title{
DAMPAK KERUSAKAN SUMBER DAYA ALAM AKIBAT PENAMBANGAN BATUBARA DI NAGARI LUNANG, KECAMATAN LUNANG SILAUT, KABUPATEN PESISIR SELATAN, PROVINSI SUMATERA BARAT
}

\author{
SURATNI AFRIANTI' ${ }^{1}$ AGUS PURWOKO² \\ 1,2 Sekolah Pascasarjana, Universitas Sumatera Utara \\ Email : suratniafrianti@gmail.com
}

\begin{abstract}
ABSTRAK
Penambangan batubara memberikan manfaat yang cukup besar terhadap peningkatan pembangunan daerah dan penyerapan tenaga kerja, sealin itu juga menberikan dampak terhadap terjadi perubahan kualitas lingkungan hidup baik lingkungan fisik, kimia, biologi maupun sosial ekonomi dan budaya masyarakat. Metode pegumpulan data ini adalah dengan mengumpulkan data skunder dari Dokument UKL/Upl, Review jurnal, buku dan tulisan ilmiah lainnya kemudian di deskriptifkan menjadi sebuah tulisan, dimana dari analisis tersebut menggambarkan bahwa tambang batubara terutama tambang terbuka akan menimbulkan dampak terjadinya perubahan bentang alam, erosi tanah, polusi udara dan air serta dampak terhadap keanekaragaman hayati setempat. Dampak dari perubahan tersebut dapat bersifat positif yang menguntungkan masyarakat tetapi juga dapat menimbulkan dampak negatif yang menurunkan kualitas lingkungan hidup.
\end{abstract}

Kata Kunci : Tambang, BatuBara, Pecemaran, Lingkungan, Dampak

\section{PENDAHULUAN}

Indonesia mempunyai sumber daya alam yang melimpah. Salah satu sumber daya alam adalah batubara, Batubara merupakan salah satu sumber daya mineral yang penting di Indonesia dan termasuk dalam golongan bahan tambang mineral organik yang dieksploitasi untuk kebutuhan sumber energi dalam negeri dan ekspor. Batubara mengandung berbagai mineral dan unsur anorganik yang berbentuk ion terlarut dalam air rembesan dan keberadaannya melimpah pada endapan batubara muda. Air rembesan ini diindikasikan mengandung logam berat yang dapat mencemari badan perairan. Pencemaran tambang batubara terhadap tanah bersifat tidak langsung. Perombakan mineral dan bahan anorganik serta racun akan menimbulkan pencemaran air. Dampak penambangan batubara lainnya berupa terjadinya pemadatan tanah oleh alatalat pertambangan dan erosi akibat pembukaan lahan (Keating, 2001).

Bahan galian batubara adalah bahan galian yang terbentuk dari sisa tumbuhan yang terperangkap dalam sedimen dan dapa dipergunakan sebagai bahan bakar, jenis sedimen ini terperangkap dan mengalami perubahan material organik akibat timbunan (Burial) dan diagenesa (Manik, 2013). Batu bara awalnya merupakan bahan organik yang terakumulasi dalam rawa-rawa yang 
Agroprimatech

Vol. 3 No. 2, April 2020

dinamakan peat (Widyati, 2009). Batu bara juga batuan organik yang memiliki sifatsifat fisika dan kimia yang kompleks yang dapat ditemui dalam berbagai bentuk. Pembentukan batu bara memerlukan kondisi-kondisi tertentu dan hanya terjadi pada era-era tertentu sepanjang sejarah geologi. Zaman karbon kira-kira 340 juta tahun yang lalu adalah masa pembentukan batu bara yang paling produktif (Jamilatun, 2008).

Batubara merupakan salah satu sumber daya mineral yang penting di Indonesia dan termasuk dalam golongan bahan tambang mineral organik yang dieksploitasi untuk kebutuhan sumber energi dalam negeri dan ekspor. Batubara mengandung berbagai mineral dan unsur anorganik yang berbentuk ion terlarut dalam air rembesan dan keberadaannya melimpah pada endapan batubara muda. Air rembesan ini diindikasikan mengandung logam berat yang dapat mencemari badan perairan. Pencemaran tambang batubara terhadap tanah bersifat tidak langsung. Perombakan mineral dan bahan anorganik serta racun akan menimbulkan pencemaran air. Dampak penambangan batubara lainnya berupa terjadinya pemadatan tanah oleh alatalat pertambangan dan erosi akibat pembukaan lahan (Keating, 2001).

Salah satu tambang batubara yang di Indonesia berada di di nagari lunang, kecamatan lunang silaut, kabupaten pesisir selatan, propinsi sumatera barat berada pada lahan seluas $199 \mathrm{Ha}$. Batubara yang dihasilkan direncanakan setiap bulannya sebesar 6.000 MT. Kegiatan pertambangan yang memanfaatkan sumberdaya alam tersebut tentunya akan menimbulkan beberapa dampak positif dan dampak negative terhadap lingkungan.

Menurut Azapagic, A., \& Perdan, S. (2000). Pengelolaan lingkungan bagi industri di bidang usaha tambang batubara merupakan hal terpenting dari suatu kegiatan usaha yang harus
e-ISSN : 2599-3232

dilakukan agar industri tetap berjalan dan berkelanjutan. Pembangunan industri yang berkelanjutan mencakup tiga aspek yaitu lingkungan (environment), ekonomi (economy) dan sosial/ kesempatan yang sama bagi semua orang (equity) yang dikenal sebagai 3E. Aspek lingkungan tidak berdiri sendiri namun sangat terkait dengan dua aspek lainnya. Dalam kegiatan internal industri, peluang untuk memadukan aspek lingkungan dan ekonomi sangat besar, tergantung cara mengelola lingkungan dengan bijak dan menguntungkan. Faktor sosial yang sebagian besar menyangkut masyarakat sekitar atau di luar industri juga sangat

terkait dalam pengelolaan lingkungan. Kaitan aspek lingkungan dengan ekonomi dan sosial dalam kegiatan industri tambang batubara merupakan hal pokok dalam menjaga dan meningkatkan kualitas kesehatan dan keselamatan masyarakat sekitar.

Berdasarkan paparan diatas maka penuliskan akan memberikan paparan tentang dampak kerusakan sumber daya alam akibat penambangan batubara di nagari lunang, kecamatan lunang silaut, kabupaten pesisir selatan, Provinsi sumatera barat.

Tujuan dari tulisan ini adalah melihat dan mendeskripsikan Dampak kerusakan sumber daya alam akibat penambangan batubara di nagari lunang, kecamatan lunang silaut, kabupaten pesisir selatan, Propinsi sumatera barat

\section{METODE PENELITIAN}

Tulisan merupakan hasil Studi Literatur, Review jurnal, buku, dokument UKL /Upl dan melakukan analogi terhadap kegiatan sejenis yang berkaitan dengan kegiatan Penambangan Batu bara yang ada di Indonesia, Kemudian di analisis menjadi sebuah tulisan deskriptif tentang dampak kerusakan sumber daya alam akibat 
Agroprimatech

Vol. 3 No. 2, April 2020

penambangan batubara di nagari lunang, kecamatan lunang silaut, kabupaten pesisir selatan, Provinsi sumatera barat.

\section{HASIL DAN PEMBAHASAN}

\section{Gambaran Umum Dampak Kerusakan Akibat Penambangan Batubara}

Lokasi kegiatan penambangan batu bara berada di Nagari Lunang, Kecamatan Lunang Silaut, Kabupaten Pesisir selatan, Propinsi Sumatera Barat. Secara geografis lokasi kegiatan berada pada 99 $12^{\prime}$ '59" Bujur Timur (BT) dan $00^{\circ}$ 14' 00" - $00^{\circ} 14$ ' 45,5" Lintang Selatan (LS). Ditinjau dari segi topografi lokasi kegiatan merupakan areal perbukitan dengan ketinggian tempat (elevasi) berada pada 250-350 meter di atas permukaan laut (mdpl). Berdasarkan Rencana Tata Ruang Wilayah (RTRW) penggunaan lahan lokasi kegiatan adalah Hutan Produksi Terbatas (HPT).

Secara ekologis lokasi penambangan batubara berada pada daerah aliran sungai Kumbung Gadang atau Sub DAS Sungai Batang Lunang yang bermuara di Samudera Hindia. Dalam Sub DAS ini dijumpai kawasan hutan alamiah dan telah disegmentasikan sebagai Hutan Penggunaan Terbatas (HPT) dan berbatasan sekitar 200 meter dengan Taman Nasional Kerinci Seblat (TNKS)

Batas-batas lokasi kegiatan yang berada dalam Izin Usaha Penambangan operasi Produksi Penambangan, Pengolahan batubara dengan kegiatan lainnya adalah sebagai berikut: Sebelah Utara berbatasan dengan hutan produksi terbatas dan hutan Lindung, Sebelah Selatan berbatasan sungai batang kumbung gadang, Sebelah Barat berbatasan dengan hutan produksi terbatas dan hutan Lindung dan Sebelah Timur berbatasan dengan hutan produksi terbatas dan hutan Lindung

Beberapa kegiatan yang akan dilakukan pada tahap penambangan
e-ISSN :2599-3232

antara lain: (1). Pembukaan lahan, (2). Penambangan batubara, (3). Pemecahan batubara (crushing), (4). Pencucian batubara (washing), (5). Penyortiran (hand picking), (6) Pengelompokan butiran (sizing).

Batubara akan mengalami pemecahan terlebih dahulu sebelum dilakukan pencucian (bila kondisi batubaranya terlalu kotor). Untuk lebih efektifnya kerja crusher, sebelumnya melalui "Vibrating Grizzly" dengan ukuran $30 \mathrm{~mm}$, sehingga batubara dengan ukuran $<30 \mathrm{~mm}$ dapat langsung tanpa proses pemecahan (by pass). Hasil dari crusher dan Undersize tersebut akan digabung pada satu belt conveyor yang berukuran $1.000 \mathrm{~mm}$. selama batubara melewati belt, maka dilakukan penyortiran kotoran yang terikat secara manual ( $h a n d$ picking). Selanjutnya batubara masuk ke unit pencucian berupa "Triple Deck Washing Screen", yang merupakan unit pencucian sederhana untuk menghilangkan kotoran penyerta dalam batubara. Tahap berikutnya adalah pengelompokan butiran (sizing) dengan menggunakan screen yang bervariasi ukurannya. Product yang dihasilkan berupa batubara dengan ukuran 0,5 mm sebagai undersize yang dipisahkan sementara bersama kotoran. Sedangkan ukuran $5-20 \mathrm{~mm}$ dan $20-30 \mathrm{~mm}$ sebagai product. Untuk product ukuran $>30 \mathrm{~mm}$ akan dipecah lagi dengan menggunkan secondary crusher yang selanjutnya melewati proses pencucian kedua dengan "Doble Deck Washing Screen". Hal ini dilakukan untuk menyempurnakan proses pencucian. Hasil sisa pencucian beserta batubara berukuran $<5 \mathrm{~mm}$ akan disalurkan melalui pipa ketempat penampungan yaitu "Sedimentation Pond".

Dampak kerusakan lingkungan yang terjadi pada lingkungan sekitar kegiatan penambangan penambangan batubara di nagari lunang, kecamatan lunang silaut, kabupaten pesisir selatan, 
Agroprimatech

Vol. 3 No. 2, April 2020

Propinsi sumatera barat antara lain adalah terjadinya pencemaran lingkungan seperti menurunyanya kualitas udara, kualitas air sungai, kualitas air tanah, biota perairan, suhu dan kelembapan udara, hilangnya keanekagaman flora, terganggunya habitat fauna, dan dampak Kesehatan masyarakat, terhadap EKonomi social dan budaya lebih jelas bisa di lihat pada gambar 1. Dibawah ini. Pertambangan merupakan suatu bidang usaha yang karena sifat kegiatannya pada dasarnya selalu menimbulkan dampak pada alam lingkungannya. Aktivitas penambangan selalu membawa dua sisi. Sisi pertama adalah memacu kemakmuran ekonomi negara. Sisi yang lain adalah timbulnya dampak lingkungan (Hidayat, 2017). Salah satu komoditi yang banyak diusahakan saat ini, untuk memenuhi kebutuhan energi di Indonesia adalah batubara. Pada saat ini Indonesia memiliki potensi sumber daya batubara sekitar 60 miliar ton dengan cadangan 7 miliar ton ( Ishlah, 2010). Dilain pihak tambang batubara pada umumnya dilakukan pada tambang terbuka (open mining), sehingga akan berdampak terhadap perubahan bentang alam, sifat fisik, kimia, dan bioligis tanah, serta secara umum menimbulkan kerusakan pada permukaan bumi. Dampak ini secara otomatis akan mengganggu ekosistem di atasnya, termasuk tata air (Subardja, 2007).

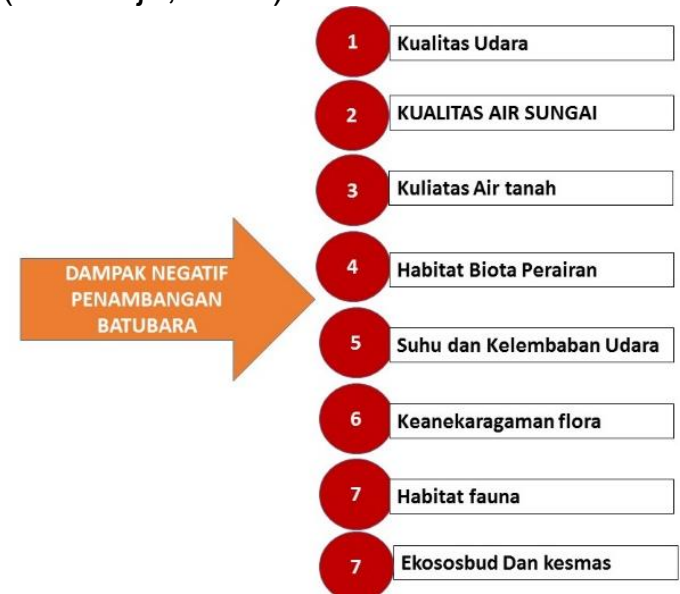

Gambar 1. Dampak Tambang BatuBara
e-ISSN : 2599-3232

\section{HASIL ANALISIS}

\section{Kualitas Udara Ambien}

Kegiatan tambang batu bara mengakibatkan terjadinya penurunan kualitas udara seperti pada saat landclearing maka akan meningkatkan kanndungan TSP, begitu juga dengan pengolahan bara akan meniingkatkan kandungan $\mathrm{SO}_{2}, \mathrm{NO}_{2}$, dan $\mathrm{CO}$ selain itu kegiatan penambangan ini juga penyebab Peningkatan kebisingan akibat suatu kegiatan dapat disebabkan oleh adanya aktivitas kendaraan yang melintas di jalan Negara yang cukup padat nantinya. Selain itu juga berasal dari operasional perusahaan yaitu penambangan batubara.

\section{Air Permukaan}

Areal penambangan batubara dilalui oleh Sungai Gadang Kumbung. Sungai tersebut memiliki kedalam 0,5 - 2 meter dengan lebar sungai rata-rata 12 meter. Berdasarkan wawancara dengan masyarakat sungai ini berair sepanjang tahun (parenial river). Sungai Gadang Kumbung ini bermuara ke Sungai Batang Kumbung dan selanjutnya bermuara ke Sungai Lunang. sumber air kegiatan operasinal berasal dari sungai Gadang Kumbung yang ditampung dalam waduk yang selanjutnya di alirkan ke water treatment plant. Secara kasat mata sungai ini berwarna kebeningan dengan arus kecepatan $2 \mathrm{~m} / \mathrm{dtk}$ (hasil observasi lapangan).

Beroperasinya penambangan batubara mempengaruhi kualitas air sungai Gadang Kumbung. Dampak yang ditimbulkan dari operasional kegiatan ini berupa penurunan kualitas air permukaan baik bersifat fisik, kimia, maupun biologi. Penurunan kualitas air permukaan ini berdampak pada gangguan habitat biota air sehingga menurunkan populasinya, serta berdampak pada masyarakat yang menggunakan air sungai untuk kebutuhan MCK. 
Agroprimatech

Vol. 3 No. 2, April 2020

hasil analisis kualitas air sungai dekat penambangan di daerah Batang Manggilang di jorong Sebrang Pasar Kenagarian Manggilang Kabupaten 50 Kota Provinasi sumatera barat sebagai analogi yang dikutip dari penelitian Rois (2018) bahwasanya Kondisi Fisika (Warna, rasa, bau, kekeruhan, suhu) didaerah kenagarian manggilang yang berada dekat sungai batang manggilang sesuai dengan uji labioratorium bahwa air sungai ini tidak memenuhi syarat untuk dipergunakan oleh masyarakat yang berada di sekitar pinggiran sungai Batang Manggilang. Karena sudah tercemari oleh keberadaan tambang batu bara. Kondisi Kimia tidak memenuhi syarat yang ditetapkan Mentri Kesehatan No 492/menkes/Kondisi Fisika (Warna, rasa, bau, kekeruhan, suhu) di daerah kenagarian manggilang yang berada dekat sungai batang manggilang sesuai dengan uji laboratorium bahwa air sungai ini tidak memenuhi syarat untuk dipergunakan oleh masyarakat yang berada di sekitar hulu sungai batang manggilang. Karena sudah tercemari oleh keberadaan tambang batu bara. Kandungan Besi pada air sungai di daerah penelitian ini tidak memenihi syarat minimum. Karena tercemarnya sungai akibat dari pertambangan batu bara yang berada di hulu sungai batang manggilang
e-ISSN :2599-3232

\section{Komponen Biologi}

\section{Vegetasi}

Dampak kerusakan lingkungan antara lain hilangnya vegetasi hutan, flora dan fauna serta lapisan tanah. Hal tersebut menyebabkan terganggunya fungsi hidrologis, serapan karbon (carbon sequestration), pemasok oksigen dan pengatur suhu lingkungan, keragaman jenis (biodiversity). Hilangnya vegetasi juga akan memberi dampak turunan terhadap Daerah Aliran Sungai yang adal Di Areal penambagan batubara seperti berkurangnya debit air sungai dampak lain adalah rusaknya bentang lahan sebagai recharge area, tingginya sedimentasi, menurunnya kualitas air sungai dan infiltrasi.

Secara umum, vegetasi bagian piggir pada kawasan ini didominasi tumbuhan oleh semak, terutama llalang dan tumbuhan perkebunan, seperti durian (Durio zibethinus), karet (Hevea brasiliensis), nangka (Artocarpus heterophyllus), dan lain-lain. Sementara itu, pada bagian sisi lainnya masih ditumbuhi tumbuhan primer, seperti Meranti (Shorea leprosula), Keruing (Dipterocarpus sp.), dan Damar (Shorea acuminatissima). Jenis-Jenis Vegetasi yang ditemukan dapat dilihat pada Tabel 1.

Tabel 1. Jenis-Jenis Vegetasi yang ditemukan di lokasi penambangan batubara sebelum kegiatan penambangan

\begin{tabular}{|c|c|c|c|c|}
\hline No & Jenis & Famili & Vern Name & $\begin{array}{c}\text { Pop } \\
\text { ula } \\
\text { si }\end{array}$ \\
\hline 1 & Dyera costulata Hook. f. & Apocynaceae & Jelutung & + \\
\hline 2 & Areca catechu L. & Arecaceae & Pinang & ++ \\
\hline 3 & Arenga pinnata Merr & Arecaceae & Aren & + \\
\hline 4 & Ageratum conyzoides L. & Asteraceae & Bandotan & + \\
\hline 5 & Clibadium surinamense L. & Asteraceae & - & $\begin{array}{c}+++ \\
+\end{array}$ \\
\hline 6 & Mikania micrantha Kunth & Asteraceae & Mikania & +++ \\
\hline 7 & Durio zibethinus Murr & Bombacaceae & Durian & $\begin{array}{c}+++ \\
++\end{array}$ \\
\hline 8 & Scleria ciliaris Nees & Cyperaceae & - & +++ \\
\hline
\end{tabular}


Agroprimatech

Vol. 3 No. 2, April 2020

e-ISSN :2599-3232

\begin{tabular}{llccc}
\hline 9 & Shorea acuminatissima Sym. & Dipterocarpaceae & Damar & + \\
10 & Dipterocarpus sp. & Dipterocarpaceae & Keruing & + \\
11 & Shorea leprosula Miq. & Dipterocarpaceae & Meranti & + \\
12 & Macaranga gigantea (Reichb. F. \& Zoll.) & Euphorbiaceae & - & +++ \\
13 & Muell Arg & Euphorbiaceae & Mara & ++ \\
14 & Macaranga tanarius (L.) M.A. & Euphorbiaceae & Karet & +++ \\
15 & Hevea brasiliensis Muell. Arg & Fabaceae & Jengkol & ++ \\
16 & Pithecellobium jiringa (Jack) Prain & Fagaceae & - & + \\
17 & Hyptis capitata Jacq. & Lamiaceae & Subang- & +++ \\
18 & Artocarpus heterophyllus Lam & Subang & + \\
19 & Piper aduncum L. & Moraceae & Nangka & + \\
20 & Imperata cylindrica (L.) Beauv. & Piperaceae & Kiseureuh & +++ \\
21 & Stachytarpheta jamaicensis (L.) Vahl & Poaceae & Ilalang & +++ \\
& & Verbenaceae & Bujang Kalam & ++ \\
& & & ++ \\
\hline
\end{tabular}

Sumber : Dok UKI/UPI, 2012

Untuk penilian nilai penting pada pohon Kawasan ini didominasi oleh jenis Karet (Hevea brasiliensis) dengan nilai penting 92,38 \%. Tumbuhan yang mendominasi berikutnya, Durian (Durio zibethinus) dengan nilai penting 56,61\%.

\section{Fauna}

Berdasarkan wawancara masyarakat sekitar, pada areal yang untuk pertambangan tidak dijumpai jejak fauna yang dilindungi, seperti Harimau, Tapir, Rusa, dan sebagainya, sedangkan dari suara yang terdengar dan pengamatan langsung ditemukan burung Enggang/Rangkok, Burung Kuau, Burung Gerunggung, Siamang dan sebagainya. Dari Informasi masyarakat, diseikitar lokasi rencana kegiatan terdapat beberapa jenis satwa yang dilindungi, seperti Siamang, Landak, Rusa dan Kijang, sedangkan Harimau sudah jarang terlihat jejaknya.

\section{Biota Perairan}

Ekosistem perairan yang berada dekat dengan lokasi pertambangan yaitu Sungai Gadang Kumbung, sungai ini tidak melewati areal penambangan, namun alirannya berada tepat dibawah lokasi pertambangan. Secara umum aliran sungai Gadang Kumbung merupakan sungai yang masih alami, terlihat airnya yang masih jernih, substrat berbatu dan berkerikil serta alirannya yang masih deras. Keadaan ini dapat berdampak kepada masih baiknya kondisi beberapa biota perairan yang terdapat di dalamnya.

Pencemaran air dapat dilihat dari kelimpahan fitoplankton. Ketika fitoplankton melimpah maka dapat dikatakan suatu perairan itu baik (Rudiyanti, S. 2009.). Keberadaan fitoplankton dapat menggambarkan parameter Biologi yang bisa digunakan untuk melihat kualitas dan kesuburan dari suatu perairan (Efendi, 2013). Pertumbuhan fitoplankton sangat tergantung oleh kondisi suatu perairan. Adapun faktor penunjang pertumbuhan fitoplankton sangat kompleks antara faktor fisika-kimia seperti intensitas cahaya, oksigen terlarut, suhu, kedalaman, $\mathrm{DO}, \mathrm{BOD}, \mathrm{COD}, \mathrm{pH}$ yang merupakan komponen yang terdapat di perairan (Silalahi,J 2009). Salah satu ekosistem perairan lotik adalah sungai (Wahyuni \& Rosanti, 2016). 
Agroprimatech

Vol. 3 No. 2, April 2020

e-ISSN :2599-3232

Tabel 2. Komposisi dan Struktur Komunitas Perifiton pada bagian Hulu Sungai Gadang Kumbung, sebelum penambangan

\begin{tabular}{|c|c|c|c|c|}
\hline No & Jenis & $\mathrm{K}$ & $\mathrm{KR}(\%)$ & $\mathrm{H}=-\sum(\mathrm{Pi} \ln \mathrm{Pi})$ \\
\hline & Crysophyta & & & \\
\hline 1 & Pinularia sp. & 2813 & 4 & 0.13 \\
\hline 2 & Cymbella affinis & 5625 & 8 & 0.20 \\
\hline 3 & Cymbella sp. & 3750 & 5 & 0.16 \\
\hline 4 & Fragillaria sp. & 4688 & 7 & 0.18 \\
\hline 5 & Gomphonema sp. & 1875 & 3 & 0.10 \\
\hline 6 & Navicula sp. & 1875 & 3 & 0.10 \\
\hline \multirow[t]{2}{*}{7} & Achnantes sp. & 938 & 1 & 0.06 \\
\hline & Chlorophyta & & & \\
\hline 8 & Oedogonium sp. & 6563 & 9 & 0.22 \\
\hline 9 & Cosmarium sp. & 4688 & 7 & 0.18 \\
\hline 10 & Cladophora sp. & 938 & 1 & 0.06 \\
\hline 11 & Zygnema sp. & 3750 & 5 & 0.16 \\
\hline 12 & Cylindrocapsa sp. & 4688 & 7 & 0.18 \\
\hline \multirow[t]{2}{*}{13} & Mikrospora sp. & 6563 & 9 & 0.22 \\
\hline & Cyanophyta & & & \\
\hline 14 & Lynbya sp. & 14063 & 20 & 0.32 \\
\hline 15 & Spirulina sp. & 1875 & 3 & 0.10 \\
\hline \multirow[t]{2}{*}{16} & Oscillatoria curviceps & 4688 & 7 & 0.18 \\
\hline & Total & 69375 & 100 & 2.56 \\
\hline
\end{tabular}

Sumber : Dok UKI/UPI, 2012

Tabel 3. Komposisi dan Struktur Komunitas Perifiton pada bagian Hilir Sungai Gadang Kumbung, sebelum penambangan

\begin{tabular}{clccc}
\hline \multicolumn{1}{c}{ Nonis } & $\mathrm{K}\left(\mathrm{idv} / \mathrm{m}^{2}\right)$ & $\mathrm{KR}(\%)$ & $\mathrm{Pi}$ lon $\mathrm{Pi}$ \\
\hline & Crysophyta & & & \\
1 & Cymbella sp & 4688 & 5 & 0.15 \\
2 & Fragillaria sp & 9375 & 10 & 0.23 \\
3 & Navicula sp & 4688 & 5 & 0.15 \\
4 & Naviculla viridula & 2813 & 3 & 0.11 \\
& Chlorophyta & & & \\
5 & Mikrospora sp & 938 & 1 & 0.05 \\
6 & Oedogonium sp & 4688 & 5 & 0.15 \\
& Cyanophyta & & & \\
7 & Oscillatoria sp & 14063 & 15 & 0.28 \\
8 & Rivularia sp & 23438 & 25 & 0.35 \\
9 & Spirulina sp & 938 & 1 & 0.05 \\
10 & Calothrix sp & 9375 & 10 & 0.23 \\
11 & Lyngbia sp & 18750 & 20 & 0.32 \\
& Total & 93750 & 100 & 2.06 \\
\hline
\end{tabular}


Agroprimatech

Vol. 3 No. 2, April 2020

e-ISSN :2599-3232

Berdasarkan hasil analisa perifiton, diketahui bahwa pada bagian hulu ditemukan jenis alga yang lebih bervariasi dibandingkan bagian hilir, yaitu sebanyak 16 jenis pada bagian hulu dan 11 jenis pada bagian hilir. Pada bagian hulu umumnya didominasi oleh kelompok alga yang berasal dari divisi Chlorophyta (alga hijau) dan diikuti oleh Crysophyta (alga emas). Dominannya alga hijau pada bagian hulu mengindikasikan suatu perairan cukup bersih atau belum mengalami pencemaran yang begitu berarti. Jenis alga seperti Zignema, Mikrospora, dan Cosmarium cendrung hidup pada perairan yang bersih. Sedagkan alga yang berasal dari jenis Crysophyta seperti Naviculla, Cymbella, Gomphonema, Achnanthes, dll cendrung hidup pada perairan bersih sampai tercemar ringan. Pada bagian hilir, jenis yang memiliki kepadatan tertinggi berasal dari divisi Cyanophyta dengan jenis yang dominan Rivularia, Oscillatoria dan Lyngbia. Pada umumnya jenis-jenis tersebut biasa ditemukan pada perairan yang tercemar ringan.

Indeks keragaman jenis tertinggi terdapat pada bagian hulu, sebesar 2,56 dan pada bagian hilir 2,06. Dari nilai yang diperoleh diketahui bahwa bagian hulu sungai relative cukup bersih dibandingkan dengan hilir yang sudah mulai dicemari limbah organik (tercemar ringan). Menurut Lee et.al, 1978 Klasifikasi derajat pencemaran berdasarkan indeks keanekaragaman $(\mathrm{H})$, yaitu $\mathrm{H}>3$ mengindikasikan perairan tidak tercemar, 2,0-3,0 tercemar sangat ringan, 1,6-2,0 tercemar ringan, 1,0- 1,5 tercemar sedang , $<1,0$ tercemar berat.

Tabel 4. Komposisi dan Struktur Komunitas Betos bagian Hulu dan Hilir Sungai Gadang Kumbung

\begin{tabular}{|c|c|c|c|c|c|c|c|}
\hline \multirow{3}{*}{$\begin{array}{l}N \\
O\end{array}$} & \multirow{3}{*}{ TAKSA } & \multicolumn{6}{|c|}{ SUNGAI GADANG KUMBUNG } \\
\hline & & \multicolumn{2}{|c|}{ HULU } & \multicolumn{2}{|c|}{ HILIR } & \multicolumn{2}{|c|}{ RATA-RATA } \\
\hline & & $\mathrm{K}$ & $\mathrm{KR}$ & $\mathrm{K}$ & $\mathrm{KR}$ & $\mathrm{K}$ & $\mathrm{KR}$ \\
\hline \multirow{5}{*}{1} & K. HIRUDINEA & 11.11 & 0.48 & & & 5.56 & 0.33 \\
\hline & O. Rhyncobdellida & 11.11 & 0.48 & & & 5.56 & 0.33 \\
\hline & Erpobdella & 11.11 & 0.48 & & & 5.56 & 0.33 \\
\hline & K. INSECTA & 2322.22 & 99.52 & 988.89 & 98.89 & 1655.56 & 99.33 \\
\hline & O. Coleoptera & 166.67 & 7.14 & 200.00 & 20.00 & 183.33 & 11.00 \\
\hline 2 & Eubrianax & 144.44 & 6.19 & 77.78 & 7.78 & 111.11 & 6.67 \\
\hline 3 & Heterlimnius & & & 66.67 & 6.67 & 33.33 & 2.00 \\
\hline 4 & Promoresia & & & 55.56 & 5.56 & 27.78 & 1.67 \\
\hline \multirow[t]{2}{*}{5} & Stenelmis & 22.22 & 0.95 & & & 11.11 & 0.67 \\
\hline & O. Diptera & 755.56 & 32.38 & 522.22 & 52.22 & 638.89 & 38.33 \\
\hline 6 & Anthoca & 100.00 & 4.29 & 122.22 & 12.22 & 111.11 & 6.67 \\
\hline 7 & Chironomidae & 622.22 & 26.67 & 355.56 & 35.56 & 488.89 & 29.33 \\
\hline \multirow[t]{2}{*}{8} & Simulium & 33.33 & 1.43 & 44.44 & 4.44 & 38.89 & 2.33 \\
\hline & O. Ephemeroptera & 988.89 & 42.38 & 122.22 & 12.22 & 555.56 & 33.33 \\
\hline 9 & Baetis & 366.67 & 15.71 & 33.33 & 3.33 & 200.00 & 12.00 \\
\hline 10 & Caenis & 55.56 & 2.38 & & & 27.78 & 1.67 \\
\hline 11 & Ecdyonurus & 22.22 & 0.95 & 11.11 & 1.11 & 16.67 & 1.00 \\
\hline 12 & Ephemerella & 144.44 & 6.19 & 22.22 & 2.22 & 83.33 & 5.00 \\
\hline
\end{tabular}


Agroprimatech

Vol. 3 No. 2, April 2020

e-ISSN :2599-3232

\begin{tabular}{|c|c|c|c|c|c|c|c|}
\hline 13 & Pseudocleon & 344.44 & 14.76 & 55.56 & 5.56 & 200.00 & 12.00 \\
\hline 14 & Leptophlebia & 55.56 & 2.38 & & & 27.78 & 1.67 \\
\hline & O. Lepidoptera & 100 & 4.29 & 22.22 & 2.22 & 61.11 & 3.67 \\
\hline 15 & Eoophyla & 100.00 & 4.29 & 22.22 & 2.22 & 61.11 & 3.67 \\
\hline & O. Megaloptera & & & 11.11 & 1.11 & 5.56 & 0.33 \\
\hline 16 & Corylidae & & & 11.11 & 1.11 & 5.56 & 0.33 \\
\hline & O. Plecoptera & 55.56 & 2.38 & 11.11 & 1.11 & 33.33 & 2 \\
\hline 17 & Perla & 44.44 & 1.90 & 11.11 & 1.11 & 27.78 & 1.67 \\
\hline 18 & Neoperla & 11.11 & 0.48 & & & 5.56 & 0.33 \\
\hline & O. Trichoptera & 255.56 & 10.95 & 111.11 & 11.11 & 183.33 & 11.00 \\
\hline 19 & Glossosoma & 55.56 & 2.38 & 88.89 & 8.89 & 72.22 & 4.33 \\
\hline 20 & Hydropsyche & 144.44 & 6.19 & 22.22 & 2.22 & 83.33 & 5.00 \\
\hline 21 & Lype & 22.22 & 0.95 & & & 11.11 & 0.67 \\
\hline 22 & Psychomiya & 33.33 & 1.43 & & & 16.67 & $\begin{array}{c}1.00 \\
100.0\end{array}$ \\
\hline & TOTAL & 2333.33 & 100.00 & 1000.00 & 100.00 & 1666.67 & 0 \\
\hline & TOTAL TAKSA & \multicolumn{2}{|c|}{19} & \multicolumn{2}{|c|}{15} & \multicolumn{2}{|c|}{22} \\
\hline & Indeks Diversitas $\left(\mathrm{H}^{\prime}\right)$ & \multicolumn{2}{|c|}{2.36} & \multicolumn{2}{|c|}{2.2} & \multicolumn{2}{|c|}{2.44} \\
\hline & Indeks Equitabilitas (E) & \multicolumn{2}{|c|}{0.80} & \multicolumn{2}{|c|}{0.81} & \multicolumn{2}{|c|}{0.79} \\
\hline
\end{tabular}

Sumber : Dok UKI/UPI, 2012

Berdasarkan Tabel 4 dapat dilihat bahwa komposisi makrozoobentos di Sungai Gadang Kumbung terdiri dari 22 genus yang tergolong kedalam dua kelas yaitu Hirudinea, dan Insecta. Dari dua kelas tersebut, Insecta merupakan kelompok makrozoobentos yang paling banyak ditemukan yaitu 21 genus, sedangkan Hirudinea hanya satu genus. Berdasarkan kepadatan, hewan bentos Sungai Gadang Kumbung didominasi oleh kelas Insecta yaitu $\mathrm{K}=1655,56$ ind $/ \mathrm{m}^{2}$ dan $\mathrm{KR}=99,33 \%$. Selanjutnya Hirudinea yaitu $\mathrm{K}=5,56 \mathrm{ind} / \mathrm{m}^{2}$ dan $\mathrm{KR}=$ $0,33 \%$.

Tingginya jumlah genera dan kepadatan relatif kelas Insecta di Sunga Gadang Kumbung disebabkan karena kondisi substrat yang cocok bagi kehidupan hewan Insecta yaitu berbatu dan berarus deras. Menurut Maula (2018) Insecta merupakan kelompok yang mendominasi komunitas hewan bentos di sungai karena Insecta memiliki anggota kelompok yang banyak.

Berdasarkan kelompok individu penyusun, hewan bentos di Sungai Gadang Kumbung didominasi oleh Chironomidae $\left(\mathrm{K}=488,89\right.$ ind $/ \mathrm{m}^{2} ; \mathrm{KR}=$ $29,33 \%$ ), selanjutnya Baetis dan Pseudocloeon dengan kepadatan yang sama yaitu $\mathrm{K}=200,00 \mathrm{ind} / \mathrm{m}^{2}$ dan $\mathrm{KR}=$ $12,00 \%$. Tingginya kepadatan kelompok hewan bentos Chironomidae disebabkan karena memiliki penyebarannya yang luas dan bersifat toleran. Menurut leksono (2010) Chironomidae dapat hidup pada berbagai macam substrat mulai dari substrat berbatu, berpasir hingga berlumpur sekalipun.

Genera lain yang memiliki kepadatan tertinggi adalah Pseudocleon dan Baetis. Tingginya kepadatan kedua genera ini diduga karena habitat yang cocok bagi kehidupan meraka. Sungai Gadang Kumbung merupakan sungai yang secara kasat mata memiliki aliran air 
Agroprimatech

Vol. 3 No. 2, April 2020

yang bersih dan jernih serta memiliki substrat berbatu dan berarus kencang. Menurut Nangin (2015), substrat sungai berbatu merupakan habitat yang paling disukai oleh kelompok hewan Ephemeroptera. Selanjutnya menurut Maula (2018), Pseudocleon merupakan genus Ephemeroptera yang umum ditemukan dan biasanya hidup pada perairan yang mulai sedikit tercemar.

Pada tabel diatas juga dapat dilihat nilai Indeks Diversitas (keanekaragaman) dan Indeks Equitabilitas (kesamarataan) pada Sungai Gadang Kumbung Bagian hulu dan bagian hilir hampir sama. Bentos pada bagian hulu memiliki nilai Indeks Diversitas yaitu 2,36 dan Indeks Equitabilitas 0,80, sedangkan bagian hilir memiliki nilai Indeks Diversitas yaitu 2,20 dan Indeks Equitabilitas 0,81. Berdasarkan nilai tersebut menunjukkan bahwa Sungai Gadang Kumbung memiliki keanekaragaman jenis yang cukup tinggi dan kepadatan populasi yang merata.

Menurut Kendeigh (1980), tinggi rendahnya nilai indeks diversitas suatu komunitas tidak hanya ditentukan oleh jumlah jenisnya saja, namun juga ditentukan oleh kesamarataan populasipopulasi dalam komunitas. Kesamarataan populasi dapat dilihat dari indeks equitabilitas dimana nilainya bergerak dari 0 - 1 bila mendekati satu berarti populasi merata dan bila mendekati nol berarti populasi tidak merata. Menurut Zairion (2003), pengelompokan sungai berdasarkan indeks kesamarataan dapat dibagi atas tiga yaitu $0,00<E \leq 0,50$ berarti komunitas berada dalam kondisi tertekan; $0,50<\mathrm{E} \leq 0,75$ berarti komunitas berada pada kondisi labil; dan $0,75<E \leq 1,00$ berarti komunitas berada pada kondisi stabil. Berdasarkan kategori tersebut maka Sungai Gadang Kumbung tergolong dalam kondisi stabil.

$$
\text { e-ISSN : 2599-3232 }
$$

\section{EKOSOSBUD DAN KESMAS}

Berkembangnya Sosial Budaya pada masyarakat maka manusia semakin lama semakin meningkat karena manusia sebagai pelaku aktivitas tersebut memiliki kebudayaan dan pola pikir yang berbeda satu dengan lainnya. Tatanan sosial barupun akhirnya membawa dampak pada berkurangnya kepercayaan, pandangan dan nilai nilai lama yang bersumber pada ajaran leluhur dan nenek moyang. Dengan adanya perusahan Pertambangan batubara dimana dari kegiatan tersebut menimbulkan permasalahan seperti pergeseran sosial budaya masyarakat.

\section{REKOMENDASI}

saran atau rekomendasi perbaikian untuk pengelolaan Kualitas udara adalah (1). Memasang alat pengendali pencemar udara yang dapat menjamin emisi tidak akan melampaui baku mutu emisi yang berlaku di Indonesia, (2). Meminimalkan emisi partikulat dari kendaraan pengangkut hasil produksi, (3). Melakukan perawatan alat-alat yang digunakan dalam pengolahanbatubara. (4). Melakukan penyiraman pada jalan yang dilalui oleh alat-alat berat dan kendaraan angkut batubara dan (5). Melakukan re-vegetasi pada areal pengolahan batubara, untuk menghalangi emisi debu ke lingkunga udara ambien.

Menjaga Kualitas air permukaan maka di saran atau di rekomendasikan untuk upaya pengelolaan adalah (1). Membuat drainase disekitar stock pile dan dilengkapi dengan sedimen trap sebelum masuk ke bak pengendapan, (2). Mengoptimalkan pengolahan dengan membuat instalasi pengolahan air limbah (IPAL), khususnya dengan bak pengendapan,(3). Optimalkan Pengolahan limbah cair dengan bantuan 
Agroprimatech

Vol. 3 No. 2, April 2020

IPAL hasil proses pemurnian, (4). Penyimpanan pelumas bekas sesuai dengan prosedur yang berlaku, (5). Pengolahan ceceran pelumas dengan membuatkan bak pengolahan pelumas seperti bak jebakan minyak.

Saran untuk Vegetasi adalah (1).

Melakukan penanaman tumbuhan dengan jenis yang sama dengan yang ditebang saat kegiatan pertambangan (2). Melakukan penanaman tumbuhan yang dapat tumbuh dengan cepat dan memiliki nilai-ekonomi yang tinggi dan estetika. Penanaman jenis ini tentunya juga memperhatikan kesesuaian lahan dan konservasi lahan.

Fauna darat adalah (1) Mempertahankan zona penyangga berupa kebun rakyat ataupun kawasan hutan alami untuk menjaga jalur migrasi fauna kedaerah wilayah lain, (2). Aktifitas peneebangan vegetasi dilakukan secara terncana dan bertahap. Sehingga kerusakan habitat alami fauna dapat diminimalisir, (3). Melakukan upaya reklamasi dengan segera pada daerahdaerah lokasi habitat dan migrasi satwa, (4). Memulihkan kembali habitat fauna yang rusak akibat kegiatan pertambangan salah satunya dengan jalan reklamasi lahan bekas tambang yang ditanam dengan tumbuhan pohon dan perdu.

Biota perairan adalah. Rekomendasi pengelolaan yang perlu dilakukan adalah setiap tahap kegiatan harus mengikuti SOP penanganan aliran air larian yang dapat mencemari badan perairan.

\section{KESIMPULAN}

Uraian Tulisan diatas bisa diambil kesimpulan bahsawanya Kegiatan penambangan batubara di nagari lunang, kecamatan lunang silaut, kabupaten pesisir selatan, Provinsi sumatera barat selain memberikan dampak positive juga memberikan dampak negatif terhadap lingkungan yaitu Terjadinya penurunan Kualitas Udara, pencemaran kualitas air
e-ISSN : 2599-3232

tanah dan air permukaan, terganggunya habitat satwa, terganggunya Vegetasi tanaman, dan dampak terhadap Ekonomi, Sosial Budaya dan Kesehatan Masyarakat.

\section{DAFTAR PUSTAKA}

Azapagic, A., \& Perdan, S. (2000). Indicators of sustainable development for industry: a general framework. Process Safety and Environmental Protection, 78(4), 243-261.

Effendi, H. (2003). Telaah kualitas air, bagi pengelolaan sumber daya dan lingkungan perairan. Kanisius.

Hidayat, L. (2017). PENGELOLAAN LINGKUNGAN AREAL TAMBANG BATUBARA. Adhum: Jurnal Penelitian dan Pengembangan IImu Administrasi dan Humaniora, 7(1), 44-52.

Ishlah, T. (2010). Kajian Pasar Mineral dan Usulan Strategi Eksplorasi Sumberdaya Mineral di Indonesia. Laporan Pusat Sumber Daya Geologi, Bandung, 13.

Keating, M. (2001). Plurinational democracy: stateless nations in a post-sovereignty era. Oxford University Press on Demand.

Leksono, A. S. (2010). Keanekaragaman hayati. Universitas Brawijaya Press.

Nangin, S. R., Langoy, M. L., \& Katili, D. Y. (2015). Makrozoobentos sebagai indikator biologis dalam menentukan kualitas air sungai 
Agroprimatech

Vol. 3 No. 2, April 2020

suhuyon Sulawesi Utara. Jurnal MIPA, 4(2), 165-168.

Maula, L. H. (2018). Keanekaragaman makrozoobentos sebagai bioindikator kualitas air Sungai Cokro Malang(Doctoral dissertation, Universitas Islam Negeri Maulana Malik Ibrahim).

Rois, M., \& Andrizal, A. (2018). Dampak Penambangan Batubara Terhadap Kualitas Air Sungai Batang Manggilang di jorong Sebrang Pasar Kenagarian Manggilang Kabupaten 50 Kota. Jurnal Geografi, 10(2), 184-190.

$$
\text { e-ISSN :2599-3232 }
$$

Rudiyanti, S. (2009). Kualitas perairan sungai Banger Pekalongan berdasarkan indikator biologis. Jurnal Saintek Perikanan, 4(2), 46-52

Silalahi, J. (2009). Analisis Kualitas Air dan Hubungannya dengan Keanekaragaman Vegetasi Akuatik di Perairan Balige Danau Toba (Master's thesis).

Zairion, D. (2003). Dampak Pembangunan Terhadap Biota Air. Makalah Kursus AMDAL, IPB. Bogor. 